\title{
THE ONE PLACE ON EARTH: A TALE OF FIVE ARCHIVES AND HENRY DAVID THOREAU
}

I RECOUNT THESE BRIEF STORIES of acquisition because I think they are in their different ways interesting, unusual, and even entertaining, at least to RBM's distinctive audience. As I retired in September 2001, this essay is also a look back over what was, for me, the most enjoyable, rewarding, and often surprising aspect of a 23 year career heading Rare Books and Special Collections at the University of Rochester Library-the acquisition of significant collections and the development of durable friendships with writers, collectors, and others in books. If a didactic strain has infiltrated these pages, it urges what most rare books/special collections directors know very well they need: (1) unfeigned respect for writers and their writing, for their papers, for books and book collectors; and (2) proactivity and perseverance. Good luck never hurts either.

For five years before coming to Rochester, I had been the late Donald Gallup's assistant in the Collection of American Literature at the Beinecke Rare Book and Manuscript Library at Yale. Always in awe of this awe-inspiring curator, I hoped to accomplish at Rochester a little of what he'd done so impressively in building the collection at Yale. With no library training beyond what I informally acquired in working at the Beinecke, I knew nothing of cataloging, reference, preservation, etc., all of which seemed self-evidently subordinate to, and dependent upon, the most fundamental aspect of library work: acquisition. Rochester had next to nothing in its modern literary collection and, 
very much an English major, I tried to address this lack, was indeed charged with addressing it.

Outstanding university though it certainly is, Rochester is not Yale, University of Rochester Rare Books and Special Collections not the Beinecke. I've witnessed the wonder-working magic of the name of Yale too often to doubt its power; the allegiance of Yale alumni has always seemed boundless, the various Beinecke acquisition funds inexhaustible. At Rochester, I was handed a list of seven potential donors that University Development permitted me to "develop." Two of them were dead. The others were like-minded. At that time, the newly established Friends of the Libraries was essentially a social club, not, in the sniffy words of its president, "accustomed to being asked for money." So I sought my own supporters and kept mum. Later, my friend Jack Kreckel, a gifted development officer with a soft heart for the library, helped us acquire more of the cash we needed. Another of the challenges of my job lay in trying to persuade whoever would listen that although the University of Rochester (UR) was indeed among the nation's wealthiest, little of its abundance trickled reliably down to the library, and even less to Rare Books and Special Collections. None, to be precise. We had several endowed acquisition funds totaling well under $\$ 100,000$ per annum, about a third of which we were required to spend on William Henry Seward. That was all.

In beginning my pursuit of literary archives, it seemed reasonable to look close to home, inasmuch as the papers of western or upstate New York writers might also constitute local history collections. However, I soon discovered that for all its millionaires, fine educational institutions, white-collar industry, and general cultural sophistication, the Rochester area boasted a surprisingly meager population of big-time writers. Joyce Carol Oates, who hailed from Lockport, nearby to the west, politely shunned my repeated archival flirtations and eventually placed the splendid tonnage of her papers with her alma mater, Syracuse University, kudos to my friend Mark Weimer there. I was tempted to court the poet 
John Ashbery, who was born just east of Rochester in the atmospheric lakeside village of Pultneyville, but realizing that sooner or later I would probably have to pretend that I understand his poetry, I hesitated. UR already owned the papers of Adelaide Crapsey, a legitimate $B A L$ poet whose only book of poetry, Verse (1915), gave literature the "cinquain," a kind of haiku-on-crack verse form she invented. I finally settled on Frederick Exley, John Gardner, Jerre Mangione, and William Heyen.

For these four authors and the African American writer John A. Williams, also a Syracuse graduate, the University of Rochester Library is now the collection of record, the one place on earth that has everything, or nearly everything they have written. We have-and have sought_-published work by these writers in every edition, printing, language, and format, from proofs to paperbacks, as well as all the original manuscripts, correspondence, and personal and professional ephemera in the author's possession at the time of acquisition and beyond, right down to shopping lists and parking tickets. Anyone undertaking serious scholarly work in these authors and their times will have to do much of it in Rochester. For most of these, and the 10 or 15 other major book and archival collections we acquired since 1978, we have the cash, care, and commitment of a small cadre of donors to thank. Most of our best collections cost the library little or nothing.

\section{Raymond R. Borst: Not of the Vast Majority of Men}

For many years, I wondered if we'd ever acquire Ray Borst's world class Thoreau library and the trove of bibliographical notes and papers that came with it. When in 1996 we finally did, the Raymond R. Borst Collection of Henry David Thoreau became the University of Rochester's best printed collection in American literature. On this collection of more than 500 volumes, including the first 16 editions of Walden (1854), Ray based his definitive Thoreau bibliography, published by the University of Pittsburgh Press in 1982, Henry David Thoreau: A 
Reference Guide (1987), and the massive Thoreau Log: A Documentary Life of Henry David Thoreau, 1817-1862 (1992). By a wonderful coincidence, the two great Thoreau scholars of modern times, Ray Borst and Walter Harding, were longtime friends and colleagues who lived within 50 miles of each other in western New York.

Though he had a conservative toughness of mind that Thoreau might have admired and served a stint as president of the Thoreau Society, Ray lived a not particularly Thoreauvian —in fact, rather baronial-life in nearby Auburn, New York, in a stately old farmhouse on 100 acres. I first met him in 1980 when he visited to work in the department; that meeting began a long friendship that ended in 2001 with his death at 91. Ray Borst was himself a rarity. How many men do you know who, having sold heavy equipment-tractors, back hoes, plows-to farmers in the first half of their lives, compiled scholarly bibliographies of nineteenth-century American transcendentalists in the second? At age 70, he taught himself bibliography and DOS and filled five-and-a-half inch floppies with Thoreau information. Like many of life's blessings, Ray's publications blossomed from loss. When his wife Anne died in midlife and a heart attack forced him to retire from his business, Ray lived alone with his books and his grief. He never remarried and never wanted to. Instead, he researched and wrote his books on Thoreau.

The informed attention of rare book curators is always validating to collectors, who may not be well understood and appreciated even by those closest to them, who are, in fact, sometimes treated with a gentle, patient contempt. Ray enjoyed the attention I enjoyed paying him. We quickly became good friends: countless lunches together at the Sherwood Inn in Skaneateles, long afternoons of book talk, visits with other bookish friends, forays into area bookstores. I even took Ray to see Titanic, the last movie he ever saw. At the same time, he toyed with me over the two decades of our friendship, using Thoreau as a kind of bibliographical wallet on a string. Speaking in one month of parting 
with his books and backing off in the next, he let me know that other libraries were in the running. He later admitted he was afraid that, having acquired his collection, I might then ignore him. What a baseless fear. Ray was a second father to me. Among the last to see him alive, I miss him every day.

When he finally committed to the University of Rochester as a home for his collection, it had a price tag that, though more than reasonable, I knew we could not meet; and I got scared. In the end, I was able to persuade Ray to donate about half the collection and, by the merest luck and the quick action of Jack Kreckel and university vice-president Roger Lathan, we secured the necessary funding from the Viburnum Foundation and landed what must have been the best Thoreau collection in private hands. The acquisition made newspapers all over the country, in Paris and London; even the Aruba Times carried a notice! A simple man who had grown accustomed to a solitary and very private life, Ray greatly enjoyed being swept up in his "15 minutes of fame," which brought him the admiration of many, as well as letters and phone calls from old friends he hadn't heard from in years. It was a sweet way to bring a long and diversely productive life gently to a close.

\section{The Bonfire of His Vanity: Frederick Exley}

The histories of our five strongest literary archival collections have this in common with Ray's Thoreau: at some point along the way, I thought we'd lost them. Frederick Exley came first. Widely admired and respected, especially among writers, Exley was born and raised in Watertown, New York, 150 miles northeast of Rochester. His remarkable book, A Fan's Notes, which won the Faulkner Award as the best first novel of 1968, is the brilliant magnum opus of a writer born, probably, to write A Fan's Notes and nothing else of major importance. Though he also authored Pages from a Cold Island (1975) and Last Notes from Home (1988), as well as several magazine pieces, A Fan's Notes is Exley's Catch- 
22, his Moby-Dick, his Great Gatsby. Read it. You'll see why. Famously alcoholic, sexist, and football-minded, Exley combined these themes with others in A Fan's Notes, which joins Catch-22 and Gatsby on Washington Post critic Jonathan Yardley's published list of the 22 best books of the twentieth century. Yardley, in fact, spent several weeks in the RBSC reading room in the spring of 1997 working the papers for his biography Misfit: The Strange Life of Frederick Exley, published later that same year.

I had been acquainted with Exley before I came to Rochester. On one Saturday morning in Hamden, Connecticut, in the spring of 1977, I had a long, loony telephone conversation with Fred in which, still airborne on the wings of Friday night's booze binge, he babbled long, incomprehensible answers to all but the bibliographical questions I'd called him about. More phone conversations and something like a friendship followed. In the fall of 1978, newly a Rochesterian, I drove up to Alexandria Bay in the Thousand Islands area to visit Fred for the first time. Arriving around 2 p.m., I was mildly surprised to find him at home, alone, sober, jauntily dressed in a crisply pressed sailor outfit right out of Pinafore, and occupying a spare, well-ordered apartment. Where was the King of the Slobs, as he'd portrayed himself in his books? Maybe the wild, drunken, to-hell-with-the-world-and-itsconventions Frederick Exley was a fiction only. After some chitchat, he set me up at a desk before a few boxes that contained "the archive," excused himself, and left the house. It took him so long to return that I began to wonder how badly I'd botch things if I left for Rochester without saying good-bye. When he finally wobbled through the door, he was so sloshed that I instantly realized good-byes were irrelevant.

It didn't take me long to see that we could not make Fred a high offer for his papers, and I figured that, his continual personal insolvency having amounted to a minor theme in A Fan's Notes, he was highly unlikely to donate. What Fred had in his apartment at the time of my visit was important, all right; there just wasn't much of it. He had published only 
two books, after all; and though it featured a sheaf of surprising and significant letters from the novelist John Cheever, a few from Robert Penn Warren, Don DeLillo, Larry McMurtry (one of which advised Fred to sell his manuscripts dear!), and others, his correspondence-always a major measure of an author's archive-was not much more extensive than his manuscripts. At that point, too, only part of the original manuscript of $A$ Fan's Notes was present. When, a year after the acquisition, Fred's sister, Frances Brown, phoned to say she'd found the rest of it, I let out a whoop.

Back in Rochester, I wrote Fred a letter full of unbridled enthusiasm for his work and a bridled purchase offer for his papers. Greeting my embarrassingly meager figure with angry, wounded sarcasm, he wrote back with the suggestion that I visit for a cookout, "using the manuscripts to start the charcoal." Always the egomaniac, Fred concluded his caustic epistle by comparing himself-not unreasonably, I might add-to F. Scott Fitzgerald, an insight that permitted me to counter with the observation that, like Exley, Fitzgerald was also neglected and uncollected even at the time of his death and that in making our offer we were anticipating - not purchasing-literary renown. This flattering and heartfelt pursuit of Fred's Fitzgerald comparison seemed palliative; he phoned with a modest counteroffer, and we soon came to terms, again through the financial assistance of a good library friend. From then until his death in 1992, Fred faithfully tossed all his correspondence, notes, drafts, photos, etc., into a box he kept under his bed, the cultivation of his archive, which now fills more than 32 boxes, having become almost as important to him as to me.

\section{John Gardner and the Infernal Revenue Service}

Once on the short list for the Nobel Prize in Literature, the late John Champlin Gardner, from nearby Batavia, New York, was a world class author whose rich, extensive archive has drawn scholars to the University of Rochester from as close by as Ithaca, as far away as Sweden and India. In July of 1978, my first year in Rochester, I purchased our nearly com- 
plete printed collection of Gardner's work—first editions of Grendel (1971), The Sunlight Dialogues (1972), and the rest. Soon thereafter, I wrote to John to inquire about his papers. We arranged to meet in a bar in Binghamton, New York, near SUNY, where he taught. Gardner waltzed unforgettably in, dressed in cowboy boots, jeans, and a leather jacket, his platinum mane cascading down around his shoulders, blue eyes twinkling abstractedly, like those of a man pleasantly daydreaming. As indeed he was. After a brief conversation, he announced that he wanted vastly more money for his papers than anyone-probably including Gardner himself-believed they were worth, and that-until 1982—was that.

Four years later, having heard nothing more about Gardner and his papers, I wrote him a clear-blue-sky letter, feeling around again. By then, the Internal Revenue Service had descended upon this intensely creative, financially innocent literary genius with a bill for nearly a half-million dollars in back taxes, an obligation which John was in no way prepared to meet and which imbued the sale of his papers with a poignant and urgent realism.

In August, my wife and I drove down to Susquehanna, Pennsylvania, to meet John and his fiance, Susan Thornton, at his home, a rambly old farmhouse out in the boonies. After touring mountain roads for what seemed like hours on a route that brought to mind certain Pollack murals, John and Susan lurching around in the back seat the whole time, we stopped for lunch in a crummy little diner that I know I could never find today. In short order, John and I shook hands on an informal agreement for the transfer of his papers to the University of Rochester, his daydream having sobered dramatically over the years.

About a month later, on September 14, 1982, just a few days before what would have been his wedding day, his motorcycle left the road while rounding a curve on the way home, and John was killed. This tragedy occurred before we had formally concluded our agreement and 
meant that we had to start over and negotiate with the executor of John's estate, a nice-enough guy who thought it would be an interesting and sexy if - as it had turned out - not very remunerative sideline to handle the financial affairs of a few literary reputations. John Irving, as I recall, and Gardner were among them.

Years passed, full of letters, delay, phone calls returned and unreturned, hassle, disappointment, temper tantrums all around, and compound hassle. For his executor, the matter of Gardner's papers had to clamber up the side of the stove to reach the back burner. Finally, on March 20, 1985, I drove to Buffalo with Library Director Jim Wyatt to sign the purchase contract at last, and on March 20, 1985, we returned to Rochester in a powerful gloom. I don't know why it occurred to me in that roomful of lawyers-I guess "IRS" flickered in the back of my mind-but just prior to signing I asked, "Is there any impediment to this deal?" One of the attorneys put two fingers to his lips, looked perplexed, disappeared for about 20 minutes, and returned to announce that the Internal Revenue Service had placed a lien on the Gardner papers!

I imagined John smiling in his grave as we tried to reason, nag, plead, and pray our way to conclusion. Though the IRS required the estate to invite bids from other universities, we had the advantage of detailed knowledge of the contents of the archive, which had been transported to the University of Rochester Library a few days after John was killed. Finally, on September 10, 1987, almost exactly five years after his death, the University of Rochester formally acquired the John Gardner Archive, proving that there is a God and it may or may not be the United States Internal Revenue Service.

\section{A Trade We Never Made: John A. Williams}

With more than 20 published books to his credit, John A. Williams is the most prolific serious African American writer in American literary 
history, his archive a major resource of UR Rare Books and Special Collections. Perhaps best known for his novels [e.g., The Man Who Cried I Am (1967) and, more recently, the astonishing Clifford's Blues (1999)], John has also published biographies of Martin Luther King and the comedian Richard Pryor as well as anthologies, essays, travel pieces, and poetry. In addition to John's own manuscripts, the archive includes his extensive personal/professional correspondence with such important black writers as Chester Himes, Ishmael Reed, John Oliver Killens, and Gwendolyn Brooks, along with a rich array of Williams family papers.

In 1985, John placed an anonymous advertisement in The Chronicle of Higher Education: "American writer, considered major by some, wishes to exchange his papers for a college education for his son." Intrigued, I responded, and when his return letter arrived, I instantly recognized his name. At the Beinecke, I had purchased several of John's many books for the great James Weldon Johnson Memorial Collection of Negro Arts and Letters, which I had served as untitled curator.

An exchange of letters and phone calls led to a first meeting at his New Jersey home, and I don't mind telling you I was a little nervous and probably even whiter than usual as I rang the doorbell at the home of the author of The Angry Black! But John was, as he always is, the most gentle and hospitable of men. In no time, we were sipping beers in his living room, as we have on many subsequent visits, and I felt I'd made a friend.

Back in Rochester, I ascended several administrators who had no idea whether we could swap education for papers, until finally I reached vice-president Bob France, who immediately blessed the project. Provost Brian Thompson did not, however, though this unexpected defeat eventually also proved a blessing. We finally purchased John's papers for a sum equivalent to the cost of four years' worth of University of Rochester education. However, at the end of his freshman year 
at Rochester John's son, Adam-now a member of a successful rock band-decided to pursue his education elsewhere, an unanticipated wrinkle that made me glad we hadn't concluded the original swap-deal after all.

So strong and important is the Williams Archive that Michele SimsBurton, a young African American English professor, recently accepted UR appointment in part, she says, because of its magnetism. This "fringe benefit" of outstanding archival collections is sometimes overlooked: first-rate faculty naturally desire to work at universities whose libraries offer first-rate support for their teaching and research.

\section{Jerre Mangione: An Ethnic's Ethnic}

In 1978, UR English professor George Grella introduced me to Jerre Mangione, a gifted member of a gifted Rochester family that includes the well-known musician Chuck Mangione, Jerre's nephew. Prior to his career as an English professor at the University of Pennsylvania, Jerre had been the national coordinating editor of the WPA's Federal Writers' Project and an accomplished novelist, historian, and social critic, always with a strong Italian emphasis. His first novel Mount Allegro (1943) is a minor classic about growing up Italian and Roman Catholic in Rochester. Jerre's Rochester roots, his literary prominence, and his connection to the FWP, of which he is the leading historian, all whetted my interest in acquiring his papers for the library. The archive included a complete run of the FWP state guides and, even better, a rich assortment of the scarce-to-rare, staple-and-stencil pamphlets that in the 1930s and 1940s poured out of the Federal Writers' Project and into virtual oblivion.

Ever fit and youthful, a jogger even into his 80 s, Jerre was a tireless and successful champion of his own writings, a man who continually berated-and occasionally fired-his agents because they failed, as he thought, to work hard enough to keep his better books in print. 
Through sheer perseverance and an abiding belief in their value, Jerre gave repeated published life to Mount Allegro, The Dream and the Deal (1972, his history of the Federal Writers' Project), and An Ethnic at Large (1978). Mount Allegro alone has had at least six major publishers, including Houghton Mifflin, Knopf, Harper's, Crown, Hill and Wang, and Columbia University Press.

Our first negotiations with Jerre went nowhere. After several letters and conversations that, though cordial, produced no agreement, I forgot about him until in 1986 I made a howyadoin' phone call to Philadelphia. He had been negotiating with library folks at the University of Pennsylvania, who had gone so far as to underwrite an extensive and expensive appraisal of Jerre's archive. Penn, however, was taking too long to suit Jerre. Ever impatient with the sluggish and-much worse-the indifferent, he promptly accepted a purchase proposal from me and, with the help of a generous donor, we acquired the seventyodd boxes of the Mangione archive and a good deal more since then.

\section{William Heyen: Poet and Collector}

None of my Rochester relationships has been more enjoyable and satisfying than my quarter-century friendship with Bill and Hannelore Heyen, whose 8,000-volume collection of modern poetry, most of it author inscribed and in mint condition, now occupies a special room in Rare Books, along with most of Bill's archive (Boston University has some early manuscripts) as one of America's finest living poets. A college soccer All-American, Bill had planned a career in physical education before the need to write poetry proved irresistible. His several major books (e.g., The Swastika Poems [1977]; Crazy Horse in Stillness [1998]) join scores of small- and fine-press publications to make Bill a prominent and interesting subject for his own collection. Most recently, Bill has edited September 11, 2001: American Writers Respond, an anthology whose title says it all. 
Almost simultaneously with his writing, Bill began to collect the work of his fellow poets, correspond with them, and seek their inscriptions in his copies of their books. During the 1960s, 1970s, and 1980s, when Bill was most passionately a collector, it was a rare day when books of his were not passing each other in the mail as they made their way to and from dealers, scouts, poets, colleagues, and friends. What finally resulted was one of the finest collections of very contemporary poetry in private hands. Of course, the book collection is intimately, profoundly connected to the archive of the Heyen papers and, with them, form an unusually strong, highly integrated body of research materials in modern poetry. In addition, Bill has personally persuaded other poets to add their papers to what is already a formidable research trove that will, if UR library management manages to stay focused, continue to evolve and strengthen.

Ever since I first met Bill in the summer of 1978, we had sought a way for his book collection and papers to come to the University of Rochester. In fact, in 1979, for safekeeping, the books were transported to the top shelves of the Rare Books stacks where for a year or two they sat in their boxes, anticipating a deal that for various reasons never transpired. In 1981, SUNY College at Brockport, where Bill was then a professor of English, hired a new president who, perceiving the great value and utility of the collection and hoping for eventual acquisition, promptly offered Bill his own room in the college library where his books could live rent free for a contractual ten-year period, Bill to retain legal ownership. That, I greatly feared, was that. Though my friendship with Bill continued unabated, I figured our loss was Brockport's gain: we had failed to act quickly enough to forestall SUNY's shrewd move.

Deep down, however, Bill always wanted his collection to go to a major research university, where it would attract the most and best use. When his agreement with Brockport expired, we began again to negotiate an understanding with Bill and, with Jack Kreckel's help, to raise 
funds for a gift/purchase. We managed to find donors for about half of the money we would need.

Jim Wyatt came up with a wonderful design for the area that was to house the Heyen Collection and then, surprising us all, retired shortly thereafter. Though Ron Dow, Jim's successor, is not the most ardent lover of poetry ever to stop by woods on a snowy evening, he certainly is an ardent and very successful wooer of donors: where others saw a mere library, Ron beheld a constellation of "naming opportunities." In Rare Books at Rochester, few objects larger than a pencil sharpener have gone nameless!

Unwilling to "leave the [Heyen] donors hanging," as he put it, the new library dean had little choice but to raise the other half of the required funds and finally conclude the project that had begun so long ago. In short, in 1998, we struck a deal with Bill and Hanny, transported the collection back again to Rochester, constructed a handsome new room that significantly expanded the department, cataloged and shelved the books, and hosted an opening gala, all in what must have been record time.

\section{The One Place on Earth}

A research university's rare books/special collections facility is its gift to the wider world of scholarship and education, its membership dues in the society of world research libraries. Everyone is welcome. We do not charge admission. Every special collections director and some librarians understand that collections such as those I've described, so rich in the raw stuff of history and literary art, so well defined and intensively focused, are not for everyone. They are indeed special. Effective use of what Rare Books and Special Collections has to offer requires the trained, experienced hands of seasoned researchers and scholars, who will from these materials fashion theses, articles, and books that will illuminate the cultural life of a civilization. 
The few collections I've described join many others in Rare Books at Rochester and in similar institutions around the world to give research libraries not just durable and important strength, but also an identity in an increasingly bland, featureless library world in which, day after day, essentially the same gray banks of computers offer access to identically the same Internet databases. If anything makes a research library distinctive today or even-as Internet use broadens and soarsredeems it from proximate irrelevance, it is likely to be its Department of Rare Books and Special Collections with its unique resources and capabilities.

Of course, I'm proud that these and all our collections and research materials are there for the ages, but the last 25 years have held other rewards as well. The men and women behind these archives and collections, their spouses and families, library staff members, the people I worked with over the years-many of these have been lifelong friends. My wife Cass and I have twice cruised the Caribbean with Bill and Hannelore Heyen, passed long weekends with Ray Borst in his cabin in the Adirondacks, enjoyed John Williams's unforgettable chili concoctions at his kitchen table. As someone once wisely observed, one's deathbed mind will probably fill not so much with work and the failures or achievements of a career but, rather, with memories of the people one has known, enjoyed, and cared about.

Sometimes things just don't work out. After my divorce in 1984, in a "lonely guy" phase of my life, I spent five consecutive Thanksgivings as a guest at the Canandaigua home of my late friend Bob Fertig and his wife, Carol. A big, talky, emotional guy with a face like Thumper, Bob led The Smugtown Stompers, a local Dixieland band whose music owed much to his hot cornet and corny singing voice. Bob collected vintage jazz records; a steel I-beam beneath the floor of his den supported the tons of rare musical wax to which we invariably adjourned 
after the turkey and cranberry sauce to relax with King Oliver and Bix Beiderbecke and a little anisette. I will never forget those warm November afternoons.

Bob had also a fine collection of Horatio Alger, Harry Castlemon, G. A Henty, Edgar Rice Burroughs, and other boys' authors. Though he knew we coveted those books, we never acquired them. In the end, he decided to leave them to his daughters, and you don't —or at least I didn't-try very hard to talk a suffering, dying man out of his final decisions, however misguided they may seem. Eventually (it may take a while), Bob's books will probably find their way into a special collections department somewhere, as fine books from the libraries of collectors so often do.

Other initiatives have come, gone, or lingered. Apparently believing that Rare Books now possesses quite enough poetry, library leadership declined first refusal to the papers of Pulitzer Prize poet Anthony Hecht, an important archive now owned by Emory University. Years ago, I invited novelists Joanna Scott, a MacArthur winner, and Tom Gavin, both of them UR professors, to deposit their papers in Rare Books, where still they safely sit. Hopefully one day that temporary home will be permanent. Finally, Rare Books has been promised the eventual gift of the world-class Gilbert and Sullivan collection of my longtime friend Dr. Harold Kanthor, at whose suggestion I've composed this little memoir. 